American Journal of Pharmacology and Toxicology 7 (1): 8-11, 2012

ISSN 1557-4962

(C) 2012 Science Publications

\title{
Evaluation of Hyypoglycemic and Hypolipidemic Activity of Nyctanthes Arbortristis Linn against Streptozotocin Induced Diabetic Rats
}

\author{
${ }^{1}$ Krishna Murti, ${ }^{1}$ Manish Kaushik and ${ }^{2}$ Aditi Kaushik \\ ${ }^{1}$ Department of Pharmacology, \\ PDM School of Pharmacy, Safidon, India \\ ${ }^{2}$ Department $\mathrm{f}$ Pharmacology Chemistry, \\ PDM College of Pharmacy, Bahadurgarh, India
}

\begin{abstract}
Problem statement: The present study was aimed to explore the hypoglycemic and hypolipidemic activity of Nyctanthes arbortristis linn roots against Streptozotocin (STZ) induced experimental rats. Approach: Ethanolic extract of roots of Nyctanthes arbortristis was administered to streptozotocin induced rats.Glibenclamide was used as a standard drug. Blood glucose levels were determined after oral administration of a dose of Nyctanthes arbortristis $\left(200 \mathrm{mg} \mathrm{kg}^{-1} \mathrm{~b}\right.$.wt) in diabetic groups. Blood glucose levels were determined on 0,7 th, 14th, 21st and 28th day after oral administration of ethanolic extracts of Nyctanthes arbortristis (200 $\left.\mathrm{mg} \mathrm{kg}^{-1}\right)$. Results: An ethanolic extract of Nyctanthes arbortristis was found to reduce blood sugar in streptozotocin induced diabetic rats. Reduction in blood sugar could be seen from 7th day after continuous administration of the extract. The effect of extracts of Nyctanthes arbortristis on serum lipid profile like Total Cholesterol, triglycerides, low density, very low density and high density lipoprotein were also measured in the diabetic and non diabetic rats. There was significant reduction in Total Cholesterol, LDL cholesterol, VLDL cholesterol and improvement in HDL cholesterol in diabetic rats. Conclusion: We concluded that Nyctanthes arbortristis possesses a hypoglycemic and hypolipidemic effect.
\end{abstract}

Key words: Nyctanthes arbortristis, glibenclamide, hypoglycemia, streptozotocin

\section{INTRODUCTION}

Diabetes mellitus is a complex disorder that characterized by hyperglycemia resulting from malfunction in insulin secretion and/or insulin action both causing by impaired metabolism of glucose, lipids and protein (Scheen, 1997). The chronic hyperglycemia of diabetes is associated with long term damage, dysfunction and failure of various organs (Lyra et al., 2006). In diabetic rats, the utilization of impaired carbohydrate leads to accelerate lipolysis, resulted in hyperlipidemia (Morel and Chisolm, 1989; Murray, 1996). Despite the presence of known antidiabetic medicine in the pharmaceutical market, diabetes and the related complications continued to be a major medical problem. Recently, some medicinal plants have been reported to be useful in diabetes worldwide and have been used empirically as antidiabetic and antihyperlipidemic remedies (Mitra et al., 1996; Shukla et al., 2000; Bhattaram et al., 2002; Mahomed and Ojewole, 2003; Hou et al., 2005; Huang et al., 2005). Diabetes mellitus is known to cause hyperlipidemia through various metabolic derangements. Among several metabolic derangements, insulin deficiency has been known to stimulate lipolysis in the adipose tissue and gives rise to hyperlipidemia and fatty liver. Thus, in diabetes hypercholesterolemia and hypertriglyceridemia often occurs (Goodman et al., 2006). More than 400 plant species having hypoglycemic activity have been available in literature (Oliver-Bever, 1986; Rai, 1995); however, searching for new antidiabetic drugs from natural plants is still attractive because they contain substances which take alternative and safe effect on diabetes mellitus. Most of plants contain glycosides, alkaloids, terpenoids, flavonoids, Carotenoids, etc., that are frequently implicated as having antidiabetic effect (Loew and Kaszkin, 2002). Nyctanthes arbortristis Linn. (Fam: Nyctanthaceae) is commonly known as 'Harsinghar' and native to India, Thailand and Indonesia, It is cultivated in gardens almost throughout India and in many tropical countries. Traditionally used to treat fevers, rheumatism, liver disorders and as expectorant. It also possesses anti-inflammatory and anthelmintic activity (Parotta, 2001; Nair and Mohanan, 2001).

\section{MATERIALS AND METHODS}

The roots of Nyctanthes arbortristis was collected from adjoining areas of Meerut, in October, 2008 and 
was authenticated by Associate Professor Dr. M. K. Saxena, Department of Botany, M.M.P.G. College campus, Modinagar, C.C.S University, Meerut (Uttar Pradesh), by carrying out macroscopic and microscopic evaluation.

Animals: Male Wistar rats of body wt. 180-200 g were obtained from central Animal House, N.K.B.R. College of Pharmacy, Meerut. The animals were fed on standard pellet diet (Hindustan Lever, Mumbai, India) and water ad libitum. The rats used in the present study were maintained in accordance with guidelines of the CPCSEA, India and the study approved by the ethical committee.

Preparation of the root extract: The shade dried roots were powdered to get a course granule. About $250 \mathrm{~g}$ of dried powder were extracted with $90 \%$ ethanol by continuous hot percolation, using soxhlet apparatus. The resulted dark - brown extract was concentrated up to $100 \mathrm{~mL}$ on Rota vapour under reduced pressure. The concentrated crude extracts were lyophilized in to powder and used for the study.

The preliminary phytochemical analysis: The preliminary phytochemical studies were performed for testing different chemical groups present in ethanolic extract (Trease et al., 1945). Phytochemical screening gave positive test for alkaloids.

Toxicity studies: The animals were divided into six groups separately and were treated orally with ethanolic extracts of Nyctanthes arbortristis at 50, 100 and 200 $\mathrm{mg} \mathrm{kg}^{-1}$, body weight doses. The animals were continuously observed for $1 \mathrm{hr}$., then frequently for 14 days. The parameters observed were grooming, hyperactivity, sedation, loss of righting reflex, respiratory rate and convulsion (Ghosh and Razmovski, 1994).

Streptozotocin-induced diabetic rats: Streptozotocin (STZ), obtained from N.K.B.R. College of Pharmacy, Meerut, was dissolved in ice-cold normal saline immediately before use. Diabetes was induced in rats by intraperitoneal (i.p) injection of streptozotocin at a dose of $50 \mathrm{mg} \mathrm{kg}^{-1}$ (Babu et al., 2003). Forty eight hours after streptozotocin administration, blood samples were drawn from tail and glucose levels determined to confirm diabetes. The rats were divided into 4 groups as follows, first group served as normal control, received food and water. Second group served as diabetic control, received $0.5 \mathrm{~mL}$ of $5 \%$ Tween 80 ; third group served as (diabetic control), received Glibenclamide (0.5 $\mathrm{mg} \mathrm{kg}^{-1}$ p.o.) and fourth groups, (diabetic rats) received $200 \mathrm{mg} \mathrm{kg}^{-1}$, b.wt. of ethanolic extracts of Nyctanthes arbortristis. The treatment was continued daily for 21days. Blood drop was collected from the tail for glucose estimation, just before drug administration on 1 st day and $1 \mathrm{~h}$ after sample administration on days 7, 14 and 21 (Table 1).

Statistical evaluation: All the data are presented as mean \pm SEM. The differences between group were evaluated by one-way Analysis Of Variance (ANOVA) followed by the Dunnette multiple comparisons test's $<0.01$ was considered to be significant.

\section{RESULTS AND DISCUSSION}

Phytochemical screening: Phytochemical screening of both the plant extracts revealed that the presence of alkaloids, phytosterols, carbohydrates and saponins.

Toxicity studies: In performing preliminary test for pharmacological activity in rats, ethanolic extract did not produce any significant changes in the behavioral or neurological responses upto $200 \mathrm{mg} \mathrm{kg}^{-1}$ body weight. Acute toxicity studies revealed the non-toxic nature of the ethanolic extracts of. Nyctanthes arbortristis. The result obtained from the LD50 study indicates that ethanolic extract of Nyctanthes arbortristis is safer to use in animals even at a dose of $200 \mathrm{mg} \mathrm{kg}^{-1}$ p.o.

Antidiabetic Effects: Effect of ethanolic extract of Nyctanthes arbortristis on serum glucose levels in diabetic rats depicted in Table 1. In animals treated with streptozotocin (50 mg kg-1 i.p) (Group II), a significant increase in serum glucose level was observed on 7 th, 14th, 21st and 28th day when compared with normal rats (Group I). Group III received Glibenclamide $(0.5$ $\mathrm{mg} \mathrm{kg}^{-1}$ p.o.) showed decrease in serum glucose level when compared with diabetic control rats (Group II). After the oral administration of ethanolic extract of Nyctanthes arbortristis in diabetic control rats, a significant reduction in blood glucose level was observed on the 7th, 14th, 21st and 28th day compared with diabetic control rats (Group II). The blood glucose level in ethanolic extract treated group showed a significant reduction from day 14 onwards (131.66 \pm 11.01$)$. Standard drug glibenclamide also showed promising effect from day 14 onwards $(128.83 \pm 19.20)$ when it was compared with diabetic control $(210.33 \pm 20.30)$. 
Am. J. Pharm. \& Toxicol., 7 (1): 8-11, 2012

Table 1: Hypoglycemic activity of extracts of Nyctanthes arbortristis on STZ induced Diabetic rats

\begin{tabular}{|c|c|c|c|c|c|}
\hline $\begin{array}{l}\text { Groups } \\
\text { Treatment/Dose }(\mathrm{Mg} / \mathrm{mL})\end{array}$ & $\begin{array}{l}0 \text { day } \\
(\mathrm{mg} / \mathrm{mL})\end{array}$ & $\begin{array}{l}\text { After } 7 \text { days } \\
(\mathrm{mg} / \mathrm{mL})\end{array}$ & $\begin{array}{l}\text { After } 14 \text { day } \\
(\mathrm{mg} / \mathrm{mL})\end{array}$ & $\begin{array}{l}\text { After } 21 \text { days } \\
(\mathrm{mg} / \mathrm{mL})\end{array}$ & $\begin{array}{l}\text { After } 28 \text { days } \\
(\mathrm{mg} / \mathrm{mL})\end{array}$ \\
\hline Normal control & $63.40 \pm 5.35$ & $96.70 \pm 5.46$ & $83.80 \pm 4.35$ & $75.74 \pm 5.89$ & $69.68 \pm 5.43$ \\
\hline Diabetic control & $223.71 \pm 15.52$ & $213.52 \pm 10.60 *$ & $210.33 \pm 20.30^{*}$ & $208.16 \pm 17.38 *$ & $202.00 \pm 16.42^{*}$ \\
\hline Glibenclamide $\left(0.5 \mathrm{mg} \mathrm{kg}^{-1}\right)$ & $231.33 \pm 13.8 * * *$ & $183.83 \pm 12.8 * * *$ & $128.83 \pm 19.20 * * *$ & $94.50 \pm 5.46 * * *$ & $91.13 \pm 12.21 * * *$ \\
\hline Ethanolic extract $\left(200 \mathrm{mg} \mathrm{kg}^{-1}\right)$ & $238.0 \pm 14.0 * * *$ & $191.16 \pm 16.13 * * *$ & $131.66 \pm 11.01 * * *$ & $97.83 \pm 10.54 * * *$ & $91.31 \pm 10.21^{* * * *}$ \\
\hline
\end{tabular}

Table 2: Hypolipidemic activity of extracts of Nyctanthes arbortristis on STZ induced Diabetic rats

\begin{tabular}{llllll}
\hline $\begin{array}{l}\text { Groups } \\
\text { Treatment/Dose }(\mathrm{mg} / \mathrm{mL})\end{array}$ & $\begin{array}{l}\mathrm{TC} \\
(\mathrm{mg} / \mathrm{mL})\end{array}$ & $\begin{array}{l}\text { TG } \\
(\mathrm{mg} / \mathrm{mL})\end{array}$ & $\begin{array}{l}\mathrm{HDL} \\
(\mathrm{mg} / \mathrm{mL})\end{array}$ & $\begin{array}{l}\mathrm{LDL} \\
(\mathrm{mg} / \mathrm{mL})\end{array}$ & $\begin{array}{l}\text { VLDL } \\
(\mathrm{mg} / \mathrm{mL})\end{array}$ \\
\hline Normal control & $81.51 \pm 1.34$ & $68.34 \pm 0.79$ & $38.83 \pm 0.68$ & $41.00 \pm 2.78$ & $18.83 \pm 0.74$ \\
Diabetic control & $134.83 \pm 1.98^{*}$ & $138.00 \pm 1.67 *$ & $45.67 \pm 1.14^{*}$ & $88.50 \pm 2.28^{*}$ & $28.34 \pm 1.68^{*}$ \\
Glibenclamide $\left(0.5 \mathrm{mg} \mathrm{kg}^{-1}\right)$ & $97.57 \pm 3.74^{* *}$ & $70.85 \pm 3.17^{* * *}$ & $35.83 \pm 5.55^{* *}$ & $45.50 \pm 1.43 * * *$ & $25.12 \pm 0.76^{* * *}$ \\
Ethanolic extract $\left(200 \mathrm{mg} \mathrm{kg}^{-1}\right)$ & $99.18 \pm 2.27^{* *}$ & $75.00 \pm 2.59^{* *}$ & $0.57 \pm 1.34 * *$ & $48.13 \pm 1.63 * *$ & $28.93 \pm 0.38^{* *}$ \\
\hline
\end{tabular}

(TC: Total Cholesterol, TG: Triglycerides, HDL: High Density Lipoprotein, LDL: Low Density Lipoprotein, VLDL: Very Low Density Lipoprotein) The values are mean \pm SEM $n=6$, when compared with diabetic control, $*=p<0.05, * *=p<0.01$, (One way ANOVA followed by Dennett's, multiple comparison tests)

Hypolipidemic activity: The lipid profiles in control and experimental rats are depicted in Table 2 in STZ induced diabetic rats. The diabetic control rats (Group II) showed significant increase in serum triglycerides, Total Cholesterol, Very Low Density Lipoproteins (VLDL), Low Density Lipoproteins (LDL) and High Density Lipoproteins (HDL) when compared with normal (Group I). Standard Glibenclamide (Group III) also reduced triglycerides, Total Cholesterol, very Low Density Lipoproteins (VLDL), Low Density Lipoproteins (LDL) and increased High Density Lipoproteins (HDL) when compared with normal (Group I).The ethanolic extract showed significant decrease $(\mathrm{p}<0.001)$ in Total Cholesterol, LDL, VLDL, Triglycerides and significant increase $(\mathrm{p}<0.001)$ in HDL when compared with diabetic control group (Group II). All these effects were observed on day 14th, 21 st and 28th. The present experimental result indicated that ethanolic extracts exhibited a potent blood glucose lowering properties in STZ diabetic rats.

\section{CONCLUSION}

Diabetes mellitus is one of the leading causes of death, illness and economic loss all over the world. Insulin-dependent (Type I, IDDM) diabetes is characterized by juvenile onset and by absolute insulin deficiency. Non-insulin-dependent (Type II, NIDDM) diabetes is characterized by mature onset, by varying basal insulin levels and a frequent association with obesity. We found an elevated blood glucose concentration accompanied by increase in total Cholesterol, triglycerides, LDL, VLDL and decrease in HDL cholesterol in streptozotocin induced diabetic rats as compared to control animals. Oral administration of ethanolic extract of Nyctanthes arbortristis normalized the levels of blood glucose. The potent antidiabetic effect of the plant extract suggests the presence of potent antidiabetic active principles, which produced antihyperglycemic effect in diabetic rats.

In recent years, considerable interest has been directed towards the investigation of plasma lipids and lipoproteins pattern in diabetes mellitus due to the fact that abnormal lipid level leads to the development of coronary artery disease in diabetic patients (Sarti and Gallagher, 2006). Reduced insulin secretion and defect in insulin function results in enhanced metabolism of lipids from adipose tissue to the plasma. Impairment in insulin sensitivity due to high concentration of lipids in the cells is responsible for the elevated cardiovascular risk in diabetes mellitus (EL-Hazmi and Warsy, 1999). Thus, the altered lipid and lipoprotein pattern observed in diabetic rats could be due to defect in insulin secretion and/or action. Hypercholesterolemia and hypertriglyceridemia have been reported to occur in alloxan-induced diabetic rats. Accumulation of cholesterol and phospholipids in liver due to elevated plasma free fatty acids has been reported in diabetic rats.

In the present study, ethanolic extract of Nyctanthes arbortristis had significantly decreased Total Cholesterol, Triglycerides, VLDL and LDL with increase in HDL which is having a protective function for the heart compared with diabetic control group.

From the above study, it can be concluded that ethanolic extract of Nyctanthes arbortristis has a potential to reduce the blood glucose level (hypoglycemic effect) and also certainly increases the HDL level in diabetic rats which is a positive sign of protective function for the heart. However, there is a need to study more about the toxicity profile of extract for future formulation studies. 
Am. J. Pharm. \& Toxicol., 7 (1): 8-11, 2012

\section{ACKNOWLEDGEMENT}

This research was carried out in the college campus of N.K.B.R. College of Pharmacy and Research Centre, Meerut. The authors are grateful to Principal and Management Trustee for constant support.

\section{REFERENCES}

Babu, V., T. Gangagadevi and A. Subramaniam, 2003. Diabetes induced by STZ in rats. Ind. J. Pharmacol., 35: 290-96.

Bhattaram, V.A., U. Ceraefe, C. Kohlest, M. Vest and H. Deundorf, 2002. Pharmacokinetics and bioavailability of herbal medicinal products. Phytomedicine, 9: 1-33. DOI: 10.1078/1433-187X00210

EL-Hazmi, M.A.F. and A.S. Warsy, 1999. Obesity, over weight and type II diabetes in Saudi adult patients. Saudi Med. J., 20: 167-172.

Ghosh, M. and V. Razmovski, 1994. Fundamentals of experimental pharmacology. Scientific Book Agency Kolkatta.

Murray, R.K., 1996. Harper's Biochemistry. 24th Edn., Appleton and Lange, Stamford, Connecticut, ISBN-10: 0838536115, pp: 868.

Goodman, L.S., A. Gilman, L.L. Brunton, J.S. Lazo and K.L. Parker, 2006. Goodman and Gilman's the Pharmacological Basis of Therapeutics. 11th Edn., McGraw-Hill Prof Med/Tech, New York, ISBN: 0071422803, pp: 2021.

Hou, Z., Z. Zhang and H. Wu, 2005. Effect of Sanguis draxonis (a Chinese traditional herb) on the formation of insulin resistance in rats. Diabetes Res. Clin. Pract., 68: 3-11. DOI: 10.1016/j.diabres.2004.08.011

Huang, T.H.W., B.P. Kota, V. Razmovski and B.D. Roufogalis, 2005. Herbal or natural medicines as modulators of peroxisome proliferator-activated receptors and related nuclear receptors for therapy of metabolic syndrome. Basic Clin. Pharmacol. Toxicol., 96: 3-14. DOI: 10.1111/j.17427843.2005.pto960102.x

Loew, D. and M. Kaszkin, 2002. Approaching the problem of bioequivalence of herbal medicinal products. Phytother. Res., 16: 705-711. DOI: 10.1002/ptr.1248
Lyra, R., M. Oliveira, D. Lins and N. Cavalcanti, 2006. Prevention of type 2 diabetes mellitus. Arq. Bras. Endocrinol. Metab., 50: 239-249. DOI: 10.1590/S0004-27302006000200010

Mahomed, I.M. and J.A. Ojewole, 2003. Hypoglycemic effect of Hypoxis hemerocallidea corm (African potato) aqueous extract in rats. Methods Find Exp. Clin. Pharmacol., 25: 617-623. DOI: 10.1358/mf.2003.25.8.778082

Mitra, S.K., S. Gopumadhavan, T.S. Muralidhar, S.D. Anturlikar and M.B. Sujatha, 1996. Effect of a herbomineral preparation D-400 in streptozotocininduced diabetic rats. J. Ethnopharmacol., 54: 4146. DOI: 10.1016/0378-8741(96)01439-0

Morel, D.W. and G.M. Chisolm, 1989. Antioxidant treatment of diabetic rats inhibits lipoprotein oxidation and cytotoxicity. J. Lipid Res., 30: 18271834.

Nair, C.K.N. and N. Mohanan, 2001. Medicinal plant of India. NAG Publication, Delhi, India.

Oliver-Bever, B., 1986. Medicinal Plants in Tropical West Africa. 1st Edn., Cambridge University Press, Cambridge, London, ISBN: 052126815X, pp: 375.

Parotta, J.A., 2001. Healing Plants of Peninsular India. 1st Edn., CAB Publisher, New York, ISBN: 0851995012, pp: 917.

Rai, M.K., 1995. A review on some antidiabetic plants of India. Ancient Science Life, 14: 42-54.

Sarti, C. and J. Gallagher, 2006. The metabolic syndrome: Prevalence, CHD risk and treatment. J. Diabetes Complicat., 20: 121-132. DOI: 10.1016/j.jdiacomp.2005.06.014

Scheen, J.A., 1997. Drug treatment of non-insulindependent diabetes mellitus in the 1990s. Achievements and future developments. Drugs, 54: 355-368. PMID: 9279500

Shukla, R., S.B. Sharma, D. Puri, K.M. Pabhu and P.S. Murthy, 2000. Medicinal plants for treatment of diabetes mellitus. Indian J. Clin. Biochem., 15: 169-177. DOI: 10.1007/BF02867556

Trease, G.E., H. E. Street and R. Bienfang, 1945. A Text-Book of Pharmacognosy. 4th Edn., Bailliere Tindall, London, pp: 799. 